\title{
Pengembangan Tekstil Berbasis Motif dan Nilai Filosofis Ornamen Tradisional Sumatra Utara
}

\author{
Daulat Saragi \\ Pendidikan Seni Rupa, \\ Fakultas Bahasa dan Seni, Universitas Negeri Medan \\ Jalan Willem Iskandar Pasar V Medan Estate, Medan 20221 \\ Email: saragios@yahoo.co.id
}

\begin{abstract}
Ethnicity and cultural diversity of North Sumatra is the pride of the communities who contribute to the wealth of cultural heritage. Nowadays, a textile development has been successfully explored with a variety of ornaments and its philosophical values, and it has been brought into fashion trends. The North Sumatra ornamental motifs contribute to the world of fashion today. Fashion designers pay big attentions to the advance of the complexity of ethnic motifs in the development of the textile world. The study was conducted by the method of documentation, observation, and interpretation of meaning of the motifs. Verstehen method (understanding) is used to interpret the symbols of ornamental motifs containing the ideas of community. The result is an alternative of textile motif development of North Sumatra-based on local patterns. With the richness of textile patterns raised from local ethnic of North Sumatra, make the fashion increasingly popular and in demand, and ultimately contributes to the development of the textile and fashion industry.
\end{abstract}

Keywords: ornamental motifs, philosophical values, textile industry

\begin{abstract}
ABSTRAK
Keanekaragaman suku dan budaya Sumatra Utara merupakan kebanggaan masyarakatnya yang berkontribusi kepada kekayaan budaya Nusantara. Perkembangan tekstil dewasa ini berhasil mengeksplorasi aneka motif dan nilai filosofis ornamen tradisi dan mengangkatnya menjadi tren mode. Motif ornamen Sumatra Utara telah berkontribusi pada dunia mode saat ini. Perancang busana melirik adanya suatu kekuatan corak etnis yang diangkat menjadi corak secara masif dalam perkembangan dunia tekstil. Penelitian dilakukan dengan menggunakan metode dokumentasi dan observasi, interpretasi atau pemaknaan, sekaligus melakukan penafsiran terhadap data yang terkumpul. Metode verstehen (pemaaman) dilakukan terhadap motif-motif ornamen sebagai simbol yang mengandung ide-ide masyarakatnya. Hasil penelitian menjadi alternatif pengembangan motif tekstil Sumatra Utara yang berbasis corak lokal. Dengan semakin kayanya corak tekstil yang diangkat dari etnis lokal Sumatra Utara akan menjadikan dunia fesyen semakin digemari dan diminati, dan akhirnya berkontribusi terhadap perkembangan industri tekstil dan fashion.
\end{abstract}

Kata kunci: motif ornamen, nilai filosofis, industri tekstil 


\section{PENDAHULUAN}

Sumatra Utara terdiri dari 8 etnis asli yang masing-masing memiliki corak kesenian yang berbeda-beda. Etnis asli tersebut adalah: Batak yang masih dibagi menjadi 6 subetnis, yaitu Toba, Simalungun, Karo, Pakpak, Mandailing dan Angkola, ditambah dengan Melayu dan Nias. Penduduk Sumatra Utara dikenal terbuka menerima suku lain di luar Sumatra Utara, sehingga dewasa ini penduduknya terdiri dari banyak suku pendatang baik dari dalam negeri seperti, Jawa, Minang, Aceh, Sunda, Madura, Ambon, Manado, dan dari luar negeri seperti India (Tamil dan Punjabi), China, Arab, dan Pakistan. Heterogenitas ini membuat Sumatra Utara cepat berkembang, baik dari segi industri, ekonomi, perdagangan, pariwisata, properti maupun dunia tekstil atau fesyen/fashion (Saragi, 2015: 76).

Keanekaragaman suku di Sumatra Utara kini membawa dampak perkembangan motif ornamen yang dimiliki masing-masing suku. Sering kali suatu lembaran kain dihiasi motif ornamen berbagai etnis di Sumatra Utara. Demikian halnya motif-motif ornamen atau ragam hias yang dimiliki masing-masing etnis kadang sudah digayakan (stylisasi) dan diubah bentuk (deformasi) sehingga kehilangan ciri khas aslinya, baik itu yang diterapkan pada kain, cinderamata, maupun hiasan pada suatu bangunan modern seperti di terminal bandara, lobi hotel, perkantoran pemerintah maupun tempat-tempat umum lainnya.

Setiap etnis daerah Sumatra Utara memiliki corak motif dan warna yang berbeda-beda membuat semakin beragamnya kekayaan keseniannya. Semua motif dan warna ornamen tersebut pada awalnya lahir dari suatu pemikiran masyarakatnya sebagai bentuk ekspresi atas interaksinya terhadap alam, manusia dan Tuhan. Ornamen merupakan pictogram atau bahasa gambar untuk mengungkapkan ekspresi jiwa. Untuk itulah perlu dilakukan pengumpulan jenis motif ornamen dari seluruh etnis di Sumatra Utara serta mengungkap filosofi makna dari setiap ornamen dimaksud (Saragi, 2015: 76).

Hampir semua suku di Indonesia mengenal seni tenun ikat yang menjadi ciri khas masyarakatnya. Sumatra Utara terkenal dengan tenunan yang dinamakan Ulos (Toba) dan Uis (Simalungun). Setiap subetnis Batak memiliki kain tenunan khas, yang selalu dipakai pada setiap upacara adat. Motif tenunan ini banyak diadopsi dari motif ornamen rumah adat Batak. Satu lembar kain tenunan mampu mengungkap beribu makna. Dengan dasar inilah, perlu diungkapkan makna dibalik motif-motif ornamen tersebut.

Perkembangan fesyen di Indonesia masa kini cenderung mengeksplorasi motif-motif tradisi, seperti motif Pekalongan, Jepara, Solo, Nusa Tenggara, Toraja, dan daerah lainnya. Motif ragam hias kedelapan etnis Sumatra Utara tidak kalah kayanya dari beberapa daerah di Nusantara. Untuk itulah perlu dilakukan inventarisasi agar masyarakat lebih mengenal dan menghargai kearifan lokal yang tidak kalah dengan daerah-daerah yang sudah terlebih dahulu dikenal orang lewat corak tekstil atau fesyen.

Hingga dewasa ini masih jarang ditemukan buku yang dapat menjadi acuan jenis motif dan makna filosofi ornamen setiap suku di Sumatra Utara. Pengertian masyarakat tentang makna filosofi ornamen ini masih dalam bentuk verbal yang diwariskan kepada generasi sesudahnya. Hal ini membuat terjadinya pengertian yang beraneka ragam sesuai dengan tafsiran beberapa penulis. Beberapa ornamen tidak sembarangan dikenakan oleh setiap orang, dan ada suatu ketentuan atau aturan mengenakan motif-motif tertentu pada pakaian. Terdapat suatu ketentuan yang hanya diketahui secara verbal dan turun-temurun tentang makna motif dan warna dari se- 
tiap motif ornamen tersebut. Untuk itulah penelitian ini sangat penting agar masyarakat mengenal dan paham akan makna motif-motif ornamen daerahnya, serta dapat berkontribusi pada pengembangan industri tekstil dengan motif-motif tradisi menuju persaingan global.

Dari latar belakang yang dikemukakan di atas, terdapat beberapa permasalahan antara lain, pertama, belum terinventarisirnya motif ragam hias dan makna filosofi ornamen 8 etnis asli Sumatra Utara. Kedua, perlunya menggambarkan kembali motif-motif ornamen yang sudah kabur atau bahkan musnah karena bangunan rumah tradisionalnya sudah diambang kerusakan. Ketiga, motif-motif ornamen daerah dapat menjadi ikon motif tekstil dan fesyen khas Sumatra Utara.

Tujuan penulisan artikel ini adalah pertama, melakukan pencarian dan inventarisasi seluruh motif ornamen 8 etnis daerah Sumatra Utara. Kedua, mencari, menemukan dan menggambarkan kembali motifmotif ornamen yang telah kabur atau yang telah berubah bentuk aslinya. Ketiga, mengungkap makna simbol setiap ornamen suku di Sumatra Utara sehingga diketahui nilai-nilai filosofis yang terkandung pada setiap motif tersebut. Penerapan ornamen 8 etnis Sumatra Utara dalam pengembangan corak tekstil dari lokal ke global ini menjadi ciri khas Sumatra Utara.

Urgensi penelitian secara teoritis yang diharapkan, yakni pertama, bermanfaat dalam upaya mengembangkan ilmu pengetahuan tentang seni, budaya dan filsafat, khususnya yang berkenaan dengan pengumpulan seluruh motif ornamen yang dimiliki suku asli di Sumatra Utara, baik pada rumah adatnya, pakaiannya dan perkakasnya. Kedua, melestarikan nilainilai kesenian lokal daerah Sumatra Utara untuk dapat dipelajari dan dikenal sehingga mampu menambah wawasan kearifan lokal yang mampu menjadi nilai pedagogik dan nilai moral masyarakatnya. Kemudian secara praktis dapat memberikan kontribusi pada pengembangan motif tekstil ataupun fesyen dari motif-motif tradisi menjadi mode atau gaya modern.

Kata 'ornamen' berasal dari bahasa Latin ornare yang artinya menghiasi yaitu komponen produk seni yang ditambahkan atau sengaja dibuat untuk hiasan, atau disebut juga penerapan hiasan dalam suatu produk (Sunaryo, 2009: 3). Seni ragam hias atau ornamen adalah seni yang tergolong tua. Sejak manusia belum mengenal aksara, mereka sudah mampu berkomunikasi atau menyampaikan buah pikirannya kepada orang lain atau kepada keturunannya kelak. Lewat coretan di tanah, di dinding gua, pada alat berburu, bahkan pada tubuhnya, mereka mengungkapkan pesan tertentu untuk diingat, diketahui orang lain dan dicitrakan lewat coretan bentukbentuk geometris, aneka gambar hewan, tumbuhan bahkan sosok dalam mimpinya. Inilah yang disebut pictogram atau bahasa gambar, atau alat kumunikasi lewat motifmotif gambar yang masih perlu ditafsirkan kembali apa makna pesan yang disampaikan (Saragi, 2015: 78)

Ornamen merupakan salah satu bentuk ekspresi kreatif manusia zaman dahulu. Ornamen dipakai untuk mendekorasi badan, dipahat pada kayu, pada tembikar, hiasan pada baju, alat-alat perang, bangunan serta benda seni lainnya (Sari dan Pramono, 2008: 73). Franz Sales Meyer (1957: vii) dalam bukunya Handbook of Ornament menyebut istilah ornamen dalam arti terbatas mengandung unsur-unsur dari hiasan yang digubah atau dikembangkan dari motif daun-daun alam, bentuk geometris dan bentuk-bentuk binatang. Dalam kesenian primitif, kepandaian hias-menghias sering lebih dipentingkan dari pada cara-cara berkesenian kemudian.

Victor Ganap (2012: 165) menyebutkan seni tradisi Nusantara yang didukung oleh 
kekayaan budaya etnik masing-masing tentunya membutuhkan perhatian para peneliti pribumi untuk menggali dan menemukan berbagai kearifan lokal dengan berbekal metodologi yang berimbang antara pendekatan etik dan emik. Peneliti seni hendaknya dapat memberlakukan seni tradisi sebagai warisan budaya yang bernilai tinggi melalui pemuliaan terhadap kearifan lokal dan tradisi lisan budaya Nusantara.

Dari beberapa pendapat di atas dapat disimpulkan bahwa ornamen adalah sebutan untuk ragam hias yang bentuknya berasal dari suatu motif yang digambar secara berulang dan meniru bentuk alam semesta yang digayakan, lalu mengubah bentuknya untuk mendapat kesan suatu gambar dekoratif.

\section{Motif ornamen sebagai simbol}

Penggunaan ornamen pada suatu benda atau bidang, tidak semata-mata untuk menampilkan bentuk yang lebih indah dari bentuk atau benda aslinya, tetapi kadangkadang lebih dari itu, yakni ingin mewujudkan atau mengutarakan maksud-maksud tertentu kepada orang lain. Bentuk ungkapan-ungkapan itu digambarkan lewat motif-motif tertentu yang mempunyai makna sebagai simbol akan kesucian, kerinduan, pengorbanan, status atau penghormatan kepada leluhur dan lain-lain. Oleh karena itu benda-benda yang dihias bermakna simbolis, dan ditempatkan tidak pada sembarang tempat atau bidang. Motif-motif simbol umumnya dikenakan pada bendabenda,seperti alat berburu, sandang, bangunan hunian, tempat sembahyang, dan alat-alat upacara ritual (Saragi, 2015: 78).

Masyarakat Mentawai menoreh tubuhnya dengan tatto tidak sekedar untuk menghadirkan unsur estetisnya, melainkan sebagai simbol adanya nilai mistis yang membuat mereka kebal terhadap benda tajam. Penekanan yang utama adalah pada makna simbolis. Mereka percaya adanya kekuatan "mana" yang dijadikan sumber dalam menghadapi tantangan. Pada akh- irnya, bentuk simbolis ini merupakan ungkapan perasaan yang dalam. Lahirnya bentuk-bentuk simbolis ini adalah manifestasi religius dari suatu masyarakat, tetapi makna simbolis yang dikandungnya mungkin berbeda dengan masyarakat lainnya (Saragi, 1996: 56).

Perkembangan ornamen mengalami pergeseran nilai dari sakral ke profan. Mulanya ornamen lahir sebagai ungkapan mistis atau religi pada masyarakat tertentu, dan kini lebih banyak berfungsi sebagai hiasan saja. Kehadiran ornamen di samping mempunyai makna simbolis juga mengandung nilai estetis. Tujuannya, untuk memperindah bidang atau permukaan. Di samping itu, tidak jarang ornamen yang dikenakan pada suatu tenunan memiliki nilai simbolik atau mengandung maksud-maksud tertentu, sesuai dengan tujuan dan gagasan pembuatnya sehingga dapat meningkatkan status sosial pemiliknya. Dengan demikian, ornamen tidak dapat dipisahkan dari kehidupan sosial budaya masyarakatnya (Sunaryo 2009: 3). Pemilihan motif ornamen tidak sembarangan, tetapi kemungkinan ada hubungan antara motif tersebut dengan kepercayaan, dengan kekuatan-kekuatan supernatural, dan harapan-harapan generasi terdahulu kepada generasi kemudian. Motif ragam hias pada suatu kain memiliki simbol status dan tingkat sosial pemakainya, dan dahulu tidak sembarang orang mengenakan kain dengan motif tertentu.

Demikian halnya dengan motif batik. Ia mempunyai banyak ragam pola dan motif yang muncul dari imajinasi yang menggambarkan cita-cita atau pengharapan. Mengupas batik tidak dapat dilepaskan dari pola dan motif, dan akan lebih menarik lagi tentunya juga berbicara dengan simbol yang melingkupi di balik wujud rupa tersebut (Sudarwanto, 2012: 108).

Berbicara motif ornamen tidak terlepas dari makna di baliknya. Motif merupakan simbol dari suatu pengalaman orang yang 
menciptakannya. Simbol muncul sebagai pernyataan atas dua hal yang disatukan dan didasarkan pada dimensinya. Motif ornamen atau hiasan yang dikenakan pada suatu busana memiliki makna sesuai dengan representasi orang yang mengenakannya. Motif tekstil tidak saja menambah nilai estetis melainkan memiliki nilai sosial pemakainya.

\section{Pola dan Jenis Hiasan}

Yang dimaksud dengan pola hias ialah unsur dasar ornamen yang dapat dipakai sebagai pedoman untuk menyusun suatu hiasan. Pola hias mengandung pengertian suatu hasil susunan dari motif hias tertentu dalam bentuk dan komposisi yang tertentu pula. Misalnya, pola hias kawung, pola hias Majapahit, Mataram, dan sebagainya (Tukiyo dan Sukarman dalam Syafii dan Rohendi, 1987: 5). Pola untuk konteks tertentu mempunyai pengertian lain. Misalnya, dalam desain produk pola ini disebut monster (produk prototipe) dari suatu barang yang akan dibuat atau digandakan (Sukarman, dalam Saragi 2015: 78).

Mengacu pada pengertian motif dan pola hias tersebut, dapat disimpulkan secara terbatas bahwa pengertian ornamen merupakan susunan pola hias yang menggunakan motif dan kaidah-kaidah tertentu pada suatu bidang atau ruang, sehingga bentuk yang dihasilkan menjadi lebih indah dan menarik perhatian.

Kedudukan ornamen dilihat dari fungsinya dapat dibagi atas tiga jenis, antara lain a) ornamen aktif (konstruktif). Ornamen ini merupakan bentuk hiasan yang tidak dapat dipisahkan dari bentuk bangunan utama dari suatu konstruksi. Apabila dihilangkan akan merusak konstruksi bentuk atau bangunan tersebut. Misalnya, bentuk tiang yang menggunakan ornamen tertentu, selain mempunyai fungsi hiasan, juga sebagai penyangga atap bangunan.

b) Hiasan pasif (non-konstruktif). Bentuk hiasan lepas dari bentuk atau bangun- an utama yang dihiasi. Apabila dibuang begitu saja tidak akan mempengaruhi bentuk atau bangunan tersebut.

c) Hiasan teknis. Bentuk hiasan disesuaikan dengan fungsinya, seperti penunjuk arah mata angin, palang pintu dan anak tangga. Di museum Simalungun Pematangsiantar, palang pintu museum dibuat dengan bentuk boraspati (cicak). Cicak tidak sekedar ornamen tetapi juga sebagai palang pintu, inilah yang disebut ornamen aktif atau konstruktif.

Menurut gaya penggambaran atau perwujudannya ornamen terdiri dari 4 gaya, yaitu 1) stilasi, distorsi, ubahan atau perubahan bentuk. Maksudnya, bentukbentuk dasar yang akan dijadikan motif mengalami penggayaan atau perubahan bentuk dari bentuk aslinya. Tujuannya, untuk menyederhanakan bentuk, menghadirkan nilai magis dan estetisnya. Penggambarannya secara dekoratif. 2) Realis dan naturalis. Maksudnya, menggambarkan bentuk-bentuk dasar yang dijadikan motif, digambarkan dengan semestinya atau sesuai dengan bentuk aslinya. 3) Idealisasi. Proses penggambaran motif dilakukan secara berlebihan atau dilebih-lebihkan, terjadi perulangan yang berlebihan dan menimbulkan kesan rumit. 4) Bebas atau kombinasi. Maksudnya, penggambaran secara bebas, terdiri dari kombinasi berbagai gaya (Saragi, 2015: 79).

\section{Sekilas tentang Masyarakat Sumatra Utara}

Sumatra Utara terdiri dari 25 Kabupaten dan 8 Kota. Suku asli Sumatra Utara terdiri dari $8 \mathrm{Suku}, 6$ diantaranya merupakan satu rumpun, yaitu Batak Toba, Batak Karo, Batak Pakpak atau Dairi, Batak Mandailing dan Angkola atau Sipirok, dan Batak Simalungun. Sedangkan dua suku lagi yaitu Melayu dan Nias. Keberadaan suku Melayu disebut dengan Melayu Deli, karena suku Melayu juga banyak terdapat di propinsi lain, seperti, Riau, Sumatra Selatan dan Bengkulu. Suku Nias agak ber- 
beda sendiri karena secara geografis suku ini tinggal jauh di luar pulau Sumatra (Saragi, 2015: 79).

Setiap suku di Sumatra Utara memiliki perbedaan kesenian yang menjadi ciri khas daerahnya, yaitu memiliki rumah adat yang berbeda, bahasa yang berbeda, ornamen atau ragam hias yang berbeda, yang menggambarkan kekayaan keragaman budaya itu. Namun demikian, sejak dulu dikenal sangat akrab dan tidak pernah terdengar atau tercatat saling berseteru walaupun berbeda agama.

Hidup rukun dan kondusif inilah yang membuat banyak para pendatang dari luar pulau Sumatra menetap di Sumatra Utara seperti di kota Medan, Pematang Siantar, Lubukpakam dan kota-kota lainnya. Karena hidup rukun inilah, kesenian masing-masing etnis juga berkembang dengan baik. Perkembangan kesenian masing-masing suku ini saling mempengaruhi satu sama lain sehingga memperkaya corak dan gaya khas Sumatra Utara.

Para antropolog menulis bahwa Sumatra Utara telah banyak dihuni suku-suku pendatang, baik suku dari dalam negeri sendiri maupun dari negara lain, seperti China, India (Tamil dan Punjabi), Pakistan dan Arab. Heterogenitas Sumatra Utara membawa berkah dengan adanya pencampuran budaya sehingga dapat menimbulkan percepatan pertumbuhan ekonomi, industri, kesenian, pariwisata dan properti.

Semakin merebaknya gaya atau tren pakaian batik di kantor pada hari tertentu, juga berdampak kepada mulai hilangnya identitas Sumatra Utara yang kaya dengan ragam hias. Walaupun sudah ada upaya membuat pakaian batik dengan motif hias Sumatra Utara, namun belum dapat menjadi jawaban pelestarian kearifan lokal Sumatra Utara, karena tetap juga mengarah kepada ciri khas batik motif Jawa. Akibatnya, banyak motif ragam hias Sumatra Utara diubah bentuk sehingga semakin mengaburkan bentuk motif aslinya.
Menurut Atmojo (2013: 91) diperlukan kemampuan menelaah muatan lokal yang mengandung berbagai macam simbol tradisional, sehingga dapat dibangun landasan penciptaan yang tidak semata-mata mengubah yang sudah ada tetapi juga mempertimbangkan serapan lokal yang bernuansa global.

Percampuran budaya di Sumatra Utara membuka peluang untuk menciptakan motif-motif dan warna hasil kreativitas yang tetap berbasis pada nilai filosofi motif lokal. Fasyen tidak lagi hanya sekedar pakaian penutup raga, tetapi dengan motif tradisi yang telah digayakan menjadi simbol prestise dan tingkat sosial masyarakat.

\section{Pengertian Tekstil dan Busana (Fesyen)}

Kata tekstil diserap dari bahasa Latin texere yang artinya menenun atau suatu aktivitas menggabung seperti benang, serat tumbuhan dan bahan-bahan lainnya menjadi lebar sehingga disebut kain. Dalam pengertian sehari-hari, tekstil berarti kain yang diperoleh atau dihasilkan dari hasil menenun, memintal, merajut, menganyam yang diperoleh dari beraneka macam serat, baik serat alami (kapas, kulit kayu, daun, dan hewani seperti wol dan sutra) maupun buatan (nilon, poliester, plastik, dan sebagainya) (Saragi, 2015: 80).

Masyarakat Indonesia sejak dahulu telah mengenal tekstil, dengan cara memintal kapas, menenunnya hingga menjadikannya selembar kain. Inilah yang dinamakan dengan istilah tenun ikat. Tekstil tenun ikat dapat ditemukan hampir di seluruh $\mathrm{Nu}-$ santara. Kain tenun dibuat dengan cara menyilangkan dua kelompok benang, benang yang membujur disebut benang lungsin, sedangkan benang yang melintang disebut dengan benang pakan. Kata ikat disebut dengan cara pembuatan motifnya digunakan pewarnaan dengan cara mengikat benang pakan atau lungsin atau keduanya, sehingga dengan warna-warna itu muncullah motif. 


\section{Perkembangan Tekstil}

William Lee berhasil menemukan mesin rajut pada masa revolusi industri di Inggris pada abad ke-17. Dengan penemuan ini berkembang jugalah teknik pewarnaan tekstil sehingga dunia tekstil sejak masa itu sangat pesat perkembangannya. Perkembangan industri selanjutnya ditemukannya mesin pemintal dan mesin tenun oleh seorang ahli kimia Perancis, Hilaire Chardonnet. Sejak itu perkembangan tekstil telah merambah ke luar Eropa, seperti Amerika, Asia, dan Afrika. Perkembangan bahan tekstil bukan lagi hanya dengan cara alami, tetapi dengan menemukan bahanbahan sintesis yang sekarang disebut rayon, seperti nilon, poliester, akrilik, dan olefin merupakan serat-serat yang dibuat dari petrokimia. Poliester bersifat tidak mudah kusut, banyak dipakai untuk bahan-bahan yang jarang disetrika, seperti gorden dan tenda. Serat akrilik sifatnya lunak dan ringan sehingga banyak dipakai untuk bahan selimut, baju hangat, dan karpet. Olefin merupakan bahan yang tidak mudah lapuk, mudah kering, dan gampang dibersihkan sehingga banyak dipergunakan untuk bahan karpet.

Kata fashion berasal dari bahasa Inggris yang kini telah diindonesiakan menjadi fesyen. Pengertian fesyen sebenarnya adalah busana yang menjadi menentukan penampilan seseorang dalam suatu acara tertentu. Fesyen kadang disebut juga untuk menunjuk mode, cara, dan gaya pakaian atau seseorang yang sedang mengenakan pakaian sehingga terlihat berbeda dari sebelumnya. Fesyen dimetaforakan sebagai gejala sosial yang membawa pesan dan gaya hidup suatu komunitas tertentu yang merupakan bagian dari kehidupan sosial. Fesyen telah menjadi gaya hidup, simbol prestise, atau status seseorang yang mengikuti hidup modern.

Seiring dengan perkembangan tekstil berdampak kepada perkembangan busana atau pakaian dan disebut dengan fesyen. Busana telah menjadi identitas dan prestise orang yang memakainya. Indonesia memiliki ciri khas fesyen, yaitu batik dan kebaya. Perkembangan batik seiring dengan perkembangan tekstil saat ini, sehingga selalu menyesuaikan dengan kebutuhan pasar. Wahyu Tri Atmojo (2011: 329-339) menjelaskan temuan-temuan bentuk cenderamata khas Batak yang kreatif dan inovatif meskipun merupakan hasil dari tiruan yang sudah ada sebelumnya. Tulisan ini dapat menjadi pembuka jalan masuk pada ragam hias yang dipakai pada cindera mata dan juga dapat diadopsi pada motif tekstil atau dunia mode atau fesyen.

Dalam tulisan Kudia, Sabhana dan Sachari (2014: 176) disebutkan perlunya dibuat disain-disain batik yang berorientasi kepada kebutuhan gaya hidup, kosmopolitan, perdagangan bebas, dan pelestarian lingkungan dengan tujuan agar bisa bersaing di pasar luar negeri. Senada dengan tulisan ini bahwa perkembangan motif tekstil harus berorientasi pasar, namun demikian perlu juga dipertahankan nilai-nilai filosofi dari setiap motif hias tekstil bagi setiap orang yang mengenakannya.

Busana sekarang ini telah menjadi simbol prestise pada masyarakat. Apalagi dengan memiliki corak yang diangkat dari motif tradisi yang memiliki makna simbolis. Di beberapa tempat di Nusantara motif ini masih dipertahankan sampai sekarang sehingga dapat membedakan ciri khas masing-masing daerah lewat fasyen yang dikenakan.

\section{METODE}

Lokasi penelitian terdiri dari 8 kabupaten, tempat bermukim 8 suku asli Sumatra Utara, yaitu Kabupaten Karo, Simalungun, Dairi, Serdang Bedagai, Tapanuli Selatan, Natal dan Kabupaten Nias. Setiap kabupaten mewakili masing-masing etnis, yaitu Batak Toba, Karo, Simalungun, Dairi, Melayu, Mandailing, Sipirok dan Nias. Populasi 
terdiri dari seluruh suku yang jumlah penduduknya besar di Sumatra Utara, yakni terdiri dari 8 suku. Teknik sampling yaitu purposif atau sampel bertujuan sehingga ditentukan sampel penelitian sasaran yakni 8 etnis asli yang dibagi atas dua tahapan yang masing-masing 4 suku tiap tahapan

Teknik pengumpulan data dilakukan melalui studi pustaka, yaitu dokumentasi hasil-hasil penelitian terdahulu. Survei atau penelitian lapangan berupa observasi mengikuti langkah-langkah Sugiyono (2010: 226). Wawancara dan dokumentasi berupa rekam gambar dengan alat kamera dan catatan tertulis. Hasil wawancara dari berbagai sumber direduksi sesuai dengan kebutuhan untuk menjawab pertanyaan penelitian. Data berikutnya diperoleh melalui wawancara tidak terstruktur untuk mengumpulkan dan mempelajari nilai-nilai filosofi dari masing-masing motif ornamen. Data yang telah digambar kembali akan disusun sesuai dengan daerahnya dan akan ditafsirkan makna filosofinya sesuai dengan hasil wawancara dan studi pustaka yang telah dilakukan.

Metode analisis data mengacu pada pendapat Kaelan (2005: 68). Langkah-langkah dalam penerapan metode analisis berturut-turut, 1) reduksi data, 2) klassifikasi data, 3) display data, dan 4) melakukan penafsiran dan interpretasi serta menarik kesimpulan. Reduksi data berkaitan dengan data verbal yang harus ditangkap maknanya. Selanjutnya, klasifikasi data, mengelompokkan data sesuai dengan ciri khasnya masing-masing. Display data yaitu pengorganisasian data dalam suatu peta yang disesuaikan dengan objek formal maupun tujuan penelitian. Langkah berikutnya adalah melakukan interpretasi atau pemaknaan, dan sekaligus melakukan penafsiranpenafsiran terhadap data yang terkumpul. Metode Verstehen (pemahaman) dilakukan terhadap motif-motif ornamen sebagai simbol-simbol, dan pemikiran-pemikiran masyarakatnya. Akhirnya, hasil penelitian disusun dengan inventarisasi gambar motif ornamen sesuai etnis, dan selanjutnya dalam bentuk deskriptif interpretatif dengan logika berpikir induktif dan deduktif (Ratna, 2010: 305).

\section{HASIL DAN PEMBAHASAN}

Secara garis besar sebanyak 6 etnis di Sumatra Utara memiliki satu rumpun, hal ini dapat dibuktikan dari pola dasar dan makna ornamen yang hampir sama. Dasar makna filosofi motif dan warna juga dapat ditelusuri persamaannya pada masingmasing etnis. Ditemukan adanya benang merah yang menyatukan dasar penggambaran setiap motif. Hal ini terjadi karena memang masih adanya kedekatan budaya dan bahasa keenam suku tersebut. Berbeda dengan suku Melayu dan Nias, motif ornamen dan warna yang dimilikinya justru sangat jauh dari 6 etnis lainnya. Namun karena terjadinya kedekatan budaya antar etnis ini membuat beberapa daerah masingmasing mengadopsi ciri khas satu sama lain. Seperti halnya motif ornamen rumah adat Mandailing hampir sama dengan motif ornamen Sipirok. Pewarnaan ornamen Melayu diadopsi dalam ornamen Mandailing, sehingga lebih kaya warna.

Demikian halnya motif ornamen pada kain tenunan masing-masing suku memiliki corak yang hampir sama. Terdapat suatu corak atau motif yang sendirinya lahir dari ekspresi yang sama pada wilayah yang berbeda. Hal ini menunjukkan adanya suatu naluri manusia untuk mencontoh atau menghadirkan sesuatu yang memiliki makna, bahkan kekuatan.

Sesuai dengan pendapat Ismail Ibrahim (2012: 22) yang menjelaskan bahwa,

Pembentukan corak ragam hias didasari oleh satu rupa kecil yang disebut motif. Motif pula adalah satu imej yang mewakili sesuatu tema, cerita/peristiwa dan ikon kepada sesuatu yang dinamakan alat, objek buatan objek semula jadi. Cerita dan makhlumat 
sesuatu motif yang didapati daripada informan akan dicerapkan melalui pemerhatian logik dan deduktif bagi mendapatkan satu rumusan. Analisis motif dan corak adalah berlandaskan kepada persepsi rekaan kontemporari.

Pembentukan motif ornamen tidaklah terjadi begitu saja, namun mengalami perenungan mendalam atau kontemplasi sehingga bentuk-bentuk alami dari gambar binatang, tumbuhan maupun manusia dirobah bentuk (distorsi), digayakan (stilasi) dan diulangi (repetisi), dan akhirnya jadilah perulangan penggambaran dan inilah yang disebut dengan ornamen. Hampir semua suku bangsa di dunia ini merasakan dan melakukan kegiatan seperti ini, sehingga jika ditelusuri pada setiap etnis, ada benang merah untuk menyatukan aktivitas yang memang benar-benar dilakukan para pendahulu kita ketika masih memiliki pola pikir sederhana.

Motif ornamen lahir dari adanya suatu keinginan untuk menyatakan sesuatu kepada orang lain, apakah itu cita, harapan, pesan, strata sosial, dan juga sebagai simbol penolak bala ataupun sebagai penjaga atau pelindung keselamatan terhadap penghuninya. Disamping itu, terdapat juga ornamen yang hanya berfungsi untuk hiasan saja atau hiasan tepi suatu gambar ornamen.

Dalam perkembangan tekstil sekarang ini, tenunan memiliki motif gabungan dari dua bahkan sampai empat etnis. Seperti halnya tenunan khas Batak Toba telah disisipi motif-motif bukan hanya dari Toba saja, melainkan penggabungan beberapa etnis. Demikian halnya tenunan Sipirok bukan hanya memakai hiasan motif Sipirok, tetapi menjadi motif gabungan beberapa etnis.

Dari hasil penelusuran pustaka dan observasi lapangan berhasil diinventaris sejumlah ornamen tiap-tiap suku yang dapat dikembangkan menjadi motif-motif tekstil yang bernuansa lokal. Motif ornamen dengan pola tumbuhan digayakan atau diubah-bentuk menjadi pola geome- tris. Demikian juga halnya motif tumbuhan juga digayakan secara berlebihan sehingga membentuk pola geometris. Beberpa pola dari suku yang berbeda dipadukan menjadi pola baru. Demikian juga dalam satu lembar kain terdiri dari perpaduan motif ornamen beberapa suku sehingga tampak lebih bervariasi dari sebelumnya.

Dari hasil penelitian, setiap pola memiliki makna dan ada juga hanya berupa hiasan tepi pemanis bidang atau hanya sebagai nilai estetisnya saja. Sifat ornamen dibagi dua, yaitu ornamen utama dan ornamen sebagai hiasan tepi yang membingkai ornamen utama. Motif ornamen yang diangkat dari bentuk alam mengalami penggayaan dan perubahan bentuk sehingga bentuk hewan atau tumbuhan digambarkan dengan bentuk geometris. Ada juga perpaduan dua pola atau tiga pola, seperti ornamen Karo yang disebut embun sikawiten (awan berarak) namun penggambarannya memakai motif tumbuhan.

Warna yang dikenakan pada setiap ornamen memiliki standar dari warna ornamen Batak Toba, yaitu hitam, merah, dan putih. Berbeda halnya pola hias Karo, Nias, Mandailing dan Melayu dikenakan warna kuning, hijau dan biru yang tentu memiliki makna yang berbeda. Warna ini masih dipercaya memiliki kekuatan magis dan disakralkan. Setiap warna memiliki makna khas dan bentuk ornamen juga ditempatkan pada tempat yang tidak sembarangan. Ada aturan penempatan ornamen sehingga tidak sembarang orang untuk menempatkannya di rumah.

Dalam bahasa Batak Toba, motif ornamen disebut dengan gorga dengan arti ukiran, sesuai dengan bentuk aslinya bahwa bentuk motif ornamen Batak Toba harus diukir pada bahan kayu rumah adat tradisional Batak tersebut. Pemakaian warna pada ornamen Batak Toba hanya tiga warna, yakni merah, hitam, dan putih. Sampai sekarang, ketiga warna itu masih diperta- 
Tabel 1. Jumlah motif ornamen 8 suku di Sumatra Utara.

\begin{tabular}{lcccccccc}
\hline Suku & Tumbuhan & Hewan & Geometris & Kosmos & Hayal & Teknis & Manusia & Jumlah \\
\hline Karo & 18 & 7 & 12 & 6 & - & 1 & - & 44 \\
Pakpak Dairi & 8 & 6 & 9 & - & 1 & - & 1 & 25 \\
Simalungun & 18 & 12 & 17 & - & - & - & 1 & 48 \\
Toba & 9 & 2 & 1 & 1 & 4 & - & 1 & 18 \\
Mandailing & 10 & 7 & 1 & 8 & - & 9 & - & 35 \\
Sipirok & 8 & 7 & 1 & 8 & - & 9 & - & 33 \\
Melayu & 28 & 1 & 10 & - & 1 & 2 & - & 42 \\
Nias & 5 & 8 & 4 & 2 & 1 & 1 & 1 & 22 \\
\hline
\end{tabular}

Sumber: Daulat Saragi, 2017

hankan tanpa memasukkan unsur warnawarna lainnya. Pemakaian warna ini sesuai dengan maknaya dan nilai-nilai filosofi ornamen tersebut. Setiap warna yang dominan menegaskan sifat kekuatan maknanya seperti sirara (dominasi warna merah), silintong (dominasi warna hitam), dan sihapas (dominasi warna putih).

Berbeda halnya penerapan ornamen Sumatra Utara di bandara Kualanamo Deli Serdang yang disesuaikan dengan fungsinya. Fungsi ornamen digunakan sebagai pemburam kaca, jadi warna ornamen dibuat dengan warna putih buram, agar tidak tembus pandang ke ruang sebelah. Pemakaian ornamen di Bandara Kualanamo memiliki ciri khas tersendiri yang disesuaikan dengan fungsinya, sehingga diubah bentuk dan warnanya, yaitu dengan berbahan plastik perekat.

Secara umum, motif ornamen kedelapan etnis di Sumatra Utara dapat dikelompokkan pada 6 motif, yaitu motif tumbuhan, hewan, geometris, kosmos, hayal dan manusia. Ada kalanya penggabungan dua atau tiga motif, seperti motif Suncang duri dengan dasar motif hewan digayakan menjadi pola geometris. Demikian halnya motif ornamen Karo yakni embun sikawiten, yang dari makna kata artinya yaitu awan berarak/beriring, namun dalam penggambarannya lebih mendekati motif tumbuhan. Setiap pola dalam ornamen tidak harus sesuai dengan sebutan nama motifnya.
Pola manusia juga digambarkan dengan pola geometris, demikian pula sebaliknya. Perkembangan selanjutnya motif-motif ornamen pada rumah adat diadopsi menjadi motif tekstil atau fesyen. Tentu saja motif ini disesuaikan dengan penggarapan suatu tenun ikat yang lebih menekankan kepada garis-garis benang kain yang akan ditenun. Jumlah pola motif ornamen masing-masing suku di Sumatra Utara dapat dilihat pada tabel 1 .

Tabel 1 merupakan hasil inventarisasi jumlah motif ornamen 8 suku di Sumatra Utara. Beberapa motif ornamen tercipta dari gabungan beberapa pola, dan terjadi dari perubahan bentuk aslinya menjadi bentuk baru. Hal ini dapat diketahui dari nama, pola dasar, dan bentuk barunya. Adakalanya motif dengan nama sejenis tumbuhan namun digambarkan dalam bentuk geometris saja, sehingga membuat suatu pola baru.

Motif tumbuhan diubah bentuk sedemikian rupa menjadi motif kosmos, seperti halnya motif ornamen Karo yang dinamakan embun sikawiten. Motif embun sikawiten (awan beriring) termasuk motif kosmos dan tumbuhan. Motif ini mengadopsi gambar awan yang divisualisasikan dengan motif tumbuhan yang merambat yang menjalin satu sama lain (Saragi, 2017: 27). Dari namanya termasuk pola kosmos namun penggambarannya dengan kombinasi motif tumbuhan dipadu dengan motif geome- 
tris, motif ini mengandung makna simbol berupa kekayan, kemakmuran, dan kebahagiaan. Motif manusia hanya mengambil bentuk bohi-bohi (wajah) dan adop (susu/payudara), yang memiliki makna kesuburan dan keibuan. Motif raksasa atau motif hayal dibuat dengan simbol sebagai penjaga harta benda, keselamatan pemilik rumah dan penolak bala berupa penyakit sampar maupun santet.

Tabel 2. Beberapa contoh motif ornamen suku di Sumatra Utara

\begin{tabular}{|c|c|c|c|c|}
\hline Nama Motif & Jenis Motif & Daerah Asal & Gambar & Nilai Filosofi / Makna Simbol \\
\hline $\begin{array}{l}\text { Embun Sikawiten } \\
\text { (Awan berarak) }\end{array}$ & Kosmos & Karo & & $\begin{array}{l}\text { Simbol kebahagiaan, kekayaan } \\
\text { dan kemakmuran pada setiap ru- } \\
\text { mah yang mengenakan motif ini. }\end{array}$ \\
\hline $\begin{array}{l}\text { Beraspati } \\
\text { (Cecak) }\end{array}$ & Hewan & Karo & & Simbol kesuburan dan pelindung. \\
\hline $\begin{array}{l}\text { Persalimbat }(\text { Jali- } \\
\text { nan = Jalin-men- } \\
\text { jalin) }\end{array}$ & Tumbuhan & Dairi & & $\begin{array}{l}\text { Simbol persatuan dan persaha- } \\
\text { batan atau keakraban pada ma- } \\
\text { syarakat Dairi. }\end{array}$ \\
\hline $\begin{array}{l}\text { Pinarasi-asi } \\
\text { (Nama Tum- } \\
\text { buhan) }\end{array}$ & Tumbuhan & Simalungun & & $\begin{array}{l}\text { Simbol kesehatan dan tanda suatu } \\
\text { musim akan terjadi. }\end{array}$ \\
\hline $\begin{array}{l}\text { Suleppat } \\
\text { (belah ketupat) }\end{array}$ & $\begin{array}{l}\text { Geometris } \\
\text { dan } \\
\text { tumbuhan }\end{array}$ & Simalungun & & $\begin{array}{l}\text { Simbol persatuan dan kesejahter- } \\
\text { aan masyarakat Simalungun. }\end{array}$ \\
\hline $\begin{array}{l}\text { Hoda-hoda } \\
\text { (Kuda) }\end{array}$ & $\begin{array}{l}\text { Manusia } \\
\text { dan Hewan }\end{array}$ & Toba & & $\begin{array}{l}\text { Simbol kegembiraan, pesta, dan } \\
\text { status seorang bangsawan atau to- } \\
\text { koh adat. }\end{array}$ \\
\hline $\begin{array}{l}\text { Ipon-ipon }(\mathrm{Gigi}= \\
\text { hiasan tepi) }\end{array}$ & Tumbuhan & Toba & & $\begin{array}{l}\text { Sebagai hiasan tepi, dan men- } \\
\text { gandung makna untuk menjaga/ } \\
\text { mengawal motif lain. }\end{array}$ \\
\hline $\begin{array}{l}\text { Bunga tabu (bun- } \\
\text { ga labu) }\end{array}$ & Tumbuhan & Simalungun & & $\begin{array}{l}\text { Simbol umur panjang, harapan se- } \\
\text { tiap orang tua. }\end{array}$ \\
\hline $\begin{array}{l}\text { Bona bulu } \\
\text { (Pohon bambu) }\end{array}$ & Geometris & Mandailing & & $\begin{array}{l}\text { Sebagai simbol sudah ada Otonomi } \\
\text { adat, budaya dan pemerintahan di } \\
\text { tengah masyarakat Mandailing. }\end{array}$ \\
\hline $\begin{array}{l}\text { Panji-panji } \\
\text { (Bendera) }\end{array}$ & Geometris & Mandailing & & $\begin{array}{l}\text { Sebagai simbol suatu tatakrama } \\
\text { dan sopan-santun sesuai dengan } \\
\text { adat-istiadat. }\end{array}$ \\
\hline $\begin{array}{l}\text { Bondul na opat } \\
\text { (Lantai dengan } \\
\text { empat sudut) }\end{array}$ & Geometris & Mandailing & & $\begin{array}{l}\text { Simbol keadilan dalam memutus- } \\
\text { kan perkara. }\end{array}$ \\
\hline $\begin{array}{l}\text { Bincar mataniari } \\
\text { (Matahari Ter- } \\
\text { bit) }\end{array}$ & Kosmos & Mandailing & & $\begin{array}{l}\text { Terbitnya matahari sebai Simbol } \\
\text { sumber kehidupan dan kese- } \\
\text { jahteraan. }\end{array}$ \\
\hline $\begin{array}{l}\text { Lebah } \\
\text { Bergantung }\end{array}$ & Geometris & Melayu & & $\begin{array}{l}\text { Simbol suatu kebaikan dan kein- } \\
\text { dahan tercipta dari kerapihan dan } \\
\text { ketertiban. }\end{array}$ \\
\hline Roda sula & Geometris & Melayu & & Simbol kekuatan dan ketahanan \\
\hline Terali biola & Geometris & Melayu & 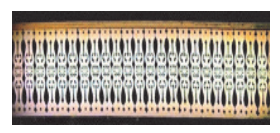 & $\begin{array}{l}\text { Simbol suatu ke-indahan tercipta } \\
\text { dari adanya ketertiban, kebaikan } \\
\text { dan kerapihan. }\end{array}$ \\
\hline Roda Bunga & $\begin{array}{l}\text { Geometris } \\
\text { dan } \\
\text { Tumbuhan }\end{array}$ & Melayu & & $\begin{array}{l}\text { Simbol kesejahteraan yang tercipta } \\
\text { dari keindahan dan pertumbuhan } \\
\text { yang baik. }\end{array}$ \\
\hline
\end{tabular}


Tabel 2. Beberapa contoh motif ornamen suku di Sumatra Utara (lanjutan)

\begin{tabular}{|c|c|c|c|c|}
\hline Nama Motif & Jenis Motif & Daerah Asal & Gambar & Nilai Filosofi / Makna Simbol \\
\hline Julun Kacang & $\begin{array}{l}\text { Tumbuhan } \\
\text { dan } \\
\text { Geometris }\end{array}$ & Melayu & & $\begin{array}{l}\text { Simbol pemersatu dalam kehidu- } \\
\text { pan masyarakat Melayu. }\end{array}$ \\
\hline Pucuk Rebung & Geometris & Melayu & & $\begin{array}{l}\text { Simbol pertumbuhan dan harapan } \\
\text { hidup bagi masyarakat Melayu. }\end{array}$ \\
\hline $\begin{array}{l}\text { Niohulayo (Mata } \\
\text { tombak) }\end{array}$ & Geometris & Nias & & $\begin{array}{l}\text { Simbol heroik dan keberanian } \\
\text { bagi masyarakat Nias. }\end{array}$ \\
\hline $\begin{array}{l}\text { Niosolafiga (Jenis } \\
\text { tumbuhan Mer- } \\
\text { ambat) }\end{array}$ & Tumbuhan & Nias & & $\begin{array}{l}\text { Simbol persatuan dan gotong ro- } \\
\text { yong bagi masyarakat Nias. }\end{array}$ \\
\hline $\begin{array}{l}\text { Niosolafiga dan } \\
\text { Niotalinga Woli- } \\
\text { woli (Tumbuhan } \\
\text { Pakis }\end{array}$ & Tumbuhan & Nias & (1) & $\begin{array}{l}\text { Simbol kesatuan, gotong royong } \\
\text { dan kesuburan bagi masyarakat } \\
\text { Nias, khususnya Nias Selatan. }\end{array}$ \\
\hline
\end{tabular}

Sumber foto: dokumentasi Daulat Saragi , tahun 2015-2016

\section{SIMPULAN}

Dari hasil penelitian yang telah dilakukan pada ke-8 etnis Sumatra Utara, penulis telah berhasil menginventaris seluruh motif ornamen dan mengungkap makna filosofi yang dikandungnya. Pada dasarnya motif ornamen yang dimiliki tiap-tiap suku pertama sekali diabadikan pada rumah adat, kemudian diadopsi dan dikembangkan dalam penerapan pada media lain. Motif mengalami perubahan jika sudah diterapkan pada tenunan karena cara penggarapannya berbeda dengan media kayu atau bambu. Dari penempatan pada rumah tradisional inilah diadobsi keberbagai media lainnya seperti, kain, atau pakaian, perkakas rumah tangga, wadah makanan dan obat-obatan hingga menghiasi alat-alat musik khas suku itu sendiri. Tidak sembarangan mengenakan motif ornamen pada setiap rumah adat, karena masing-masing motif memiliki nilai-nilai filosofi yang berbeda-beda. Demikian halnya penerapan motif pada selembar kain pada mulanya memiliki aturan secara adat, namun kini motif itu hanya menonjolkan nilai estetikanya saja

Para desainer sekarang ini banyak mengangkat ragam hias etnis, sehingga ornamen daerah menjadi kebanggaan tersendiri bagi pasar busana. Demikian juga dunia industri saat ini telah melirik motif ragam hias Sumatra Utara untuk dicetak secara massal, sehubungan dengan adanya upaya pemerintah daerah untuk mengenakan dinas kantor maupun dinas sekolah dengan kain bercorak ragam hias etnis daerahnya masing-masing.

Hasil penelitian ini diharapkan dapat menjadi alternatif pedoman pengembangan industri tekstil corak etnis Sumatra Utara. Dengan demikian, masyarakat dapat lebih memamahami makna filosofi dari berbagai motif fasyen yang dikenakannya.

Nilai-nilai filosofi yang terkandung pada setiap motif ornamen akan menjadi referensi bukti kearifan lokal masyarakat Sumatra Utara, sehingga temuan kebijakan lokal (local wisdom) akan dapat disumbangkan menjadi dasar filsafat Nusantara (nation wisdom). Dengan konstribusi ini akan semakin nyata bahwa budaya dan filsafat Nusantara akan kuat apabila digali dari kekayaan budaya dan pandangan hidup atau filsafat dari suku bangsanya sendiri

Penemuan nilai-nilai budaya lama dan pelestariannya akan dibukukan serta dipatenkan agar menjadi kekayaan intelektual yang nantinya tidak dapat lagi diklaim bangsa lain. Nilai-nilai filososfi makna or- 
namen atau ragam hias yang ditemukan dapat disumbangkan untuk memperkaya nilai-nilai Filsafat Nusantara. Oleh sebab itu, perlu adanya pengembangan atau pengangkatan nilai-nilai tradisi menjadi komsumsi global khususnya bidang industri tekstil dan fesyen. Dengan adanya buku album gambar motif-motif ornamen dari 8 etnis di Sumatra Utara, maka akan dapat menjadi acuan untuk pengembangan motif-motif tradisi yang akan diterapkan pada tekstil atau dunia mode (fashion/ fesyen).

Disarankan kepada pihak dinas perindustrian Provinsi Sumatra Utara agar lebih aktif, reaktif dan kreatif dalam hal penggalian nilai-nilai budaya Sumatra Utara dan mengaplikasikannya dalam berbagai ragam produk hasil industri kreatif Sumatra Utara.

Diharapkan adanya kerjasama lintas dinas dengan para disainer untuk memperkenalkan corak fasyen khas Sumatra Utara lewat hiburan dan peragaan busana yang dilakukan secara rutin, baik dalam skala nasional maupun internasional.

\section{Daftar Pustaka}

Atmojo, T., W. (2011). Cendramata Berbasis Seni Etnik Batak. Panggung, 21 (3), 329-339.

. (2013). Penciptaan Batik Melayu Sumatra Utara. Panggung, 23 (1), 90-97.

Ganap, V. (2012). Konsep Multikultural dan Etnisitas Pribumi dalam Penelitian Seni. Humaniora, 24 (2), 156-167.

Ibrahim, I. (2012). Pembentukan Motif/Corak dan Hubungannya dalam Ruang Lingkup Kehidupan Murut Borneo Utara, Proceding Seminar Internasional Tema: Warisan Nusantara. Universitas Negeri Semarang, Semarang.

Kaelan. (2005). Metode Penelitian Kualitatif bidang Filsafat. Yogjakarta: Paradigma.

Kudia, K., Sabana, S., Sachari, A. (2014). Revitalisasi Ragam Hias Batik Keraton
Cirebon dalam Desain Baru Kreatif. Panggung, 24 (2), 175-186.

Ratna, K. N. (2010). Metodologi Penelitian Kajian Budaya dan Ilmu Sosial Humaniora Pada Umumnya. Yogyakarta: Pustaka Pelajar.

Saragi, D. (2017). Jenis Motif dan Nilai Filosofis Ornamen Tradidional Sumatra Utara. Yogyakarta: Thafa Media.

-. (2015). Inventarisasi Jenis Motif dan Nilai Filosofis Ornamen Tradisional Sumatra Utara Guna Pengembangan Industri Tekstil Berbasis Corak Ornamen Lokal dalam Prosiding Seminar dan Rapat Tahunan BKS PTN Wilayah Barat Bidang: Bahasa, Sastra, Seni dan Budaya, Fakultas Bahasa dan Seni Universitas Negeri Jakarta, Jakarta.

. (2012). Mengungkap Nilai Pedagogis dan Ajaran Moral yang Terkandung Dalam Makna Ornamen Tradisional Rumah adat Batak Simalungun sebagai Konstribusi Pendidikan Karakter Bangsa, Hasil Penelitian LEMLIT Unimed, Medan

(2009). Mengungkap Nilai Pedagogis dan Nilai Estetika Yang Terkandung dalam Makna Motif Ornamen Tradisional Rumah Adat Batak Toba, Hasil Penelitian, Lemlit Unimed, Medan.

Sari, M., S. dan Pramon, S., R. (2008). Kajian Ikonografis Ornamen Pada Interior Klenteng Sanggar Agung Surabaya. Dimensi Interior. Jurnal Desain Interior, 6 (2), 73-84.

Sukarman. (1983). Pengantar Ornamen Timur I, Proyek STSRI “ASRI” Proyek Pengembangan IKIP Jakarta, Jakarta.

Sugiyono. (2010). Metode Penelitian Kuantitatif Kualitatif dan RED. Bandung: Alfabeta.

Sudarwanto, A. (2012). Rupa dan makna Simbolis Batik Motif Modang, Cemukiran. Jurnal Dewa Ruci, 8 (1), 107-123. 
Sunaryo, A. (2009). Ornamen Nusantara Kajian Khusus tentang Ornamen Indonesia. Semarang: Dahara Prize.
Syafii dan Rohendi, T., R. (1987). Ornamen Ukir. Semarang: IKIP Semarang Press. 